\title{
The August 2002 earthquake sequence in north Afar: Insights into the neotectonics of the Danakil microplate
}

\author{
Atalay Ayele ${ }^{\mathrm{a}, *}$, Graham Stuart ${ }^{\mathrm{b}}$, Ian Bastow ${ }^{\mathrm{b}}$, Derek Keir ${ }^{\mathrm{c}}$ \\ ${ }^{a}$ Geophysical Observatory, Addis Ababa University, Box 1176, Addis Ababa, Ethiopia \\ ${ }^{\mathrm{b}}$ School of Earth and the Environment, University of Leeds, Leeds LS2 9JT, UK \\ ${ }^{c}$ Department of Geology, Royal Hollway University of London, Egham TW20 OEX, UK
}

Received 18 June 2005; received in revised form 2 February 2006; accepted 1 June 2006

Available online 14 March 2007

\begin{abstract}
In August 2002, there was high seismic activity in Afar concentrated at the plateau margin of the northern Ethiopian rift east of Mekele, near the western part of the Danakil microplate. The spatial and temporal distributions of this seismic activity over four weeks indicate the NNW propagation of the Gulf of Aden rift across the Afar Depression towards the western Ethiopian plateau. Fault plane solutions for six larger earthquakes from the August 2002 sequence are estimated from moment tensor inversion of local broadband waveform data. The results show only normal faulting on NNW trending and NE dipping faults, which agree with tectonics of the area and distribution of aftershocks. No strike-slip component is observed in any of our fault plane solutions or those of other workers including Harvard CMT solutions in the region. Such motion would be indicative of oblique-slip deformation between the Nubian plate and the Danakil microplate consistent with counter-clockwise rotation of the microplate. Hypocentral depths of well-constrained events are 5-7 km, which is the approximate elastic plate thickness in the Main Ethiopian rift, possibly indicating the depth to the brittle-ductile transition zone in this part of the Afar Depression. The shallowness of the depth estimates agree with the macroseismic reports available from a wide area in northern Ethiopia. Potential future shallow crustal deformation may cause significant loss of human life and damage to property in the densely populated highland region around Mekele unless measures are taken in improving building standards. The $b$-value for this sequence is estimated to be 0.66 using a least squares fit, while it is $0.67 \pm 0.16$ from a maximum-likelihood approach. This estimated $b$-value is low or the frequency of occurrence of relatively larger magnitude events is high indicating that it is a highly stressed region as evidenced by the recent increase of the seismicity in the area.
\end{abstract}

(c) 2007 Elsevier Ltd. All rights reserved.

Keywords: Afar; Danakil microplate; Fault-plane solutions; Seismicity; $b$-Value

\section{Introduction}

The Afar Depression is a diffuse extensional province in the region where the Gulf of Aden, the Red Sea and the Main Ethiopian rift approach one another (Fig. 1a). The three extensional plate boundaries are different in age (Barberi et al., 1972; Cochran, 1981; Manighetti et al., 1998; Wolfenden et al., 2004) and divergence rate (Chu and Gordon, 1998; Bilham et al., 1999) but each tends to extend

\footnotetext{
${ }^{*}$ Corresponding author.

E-mail address: atalay@geobs.aau.edu.et (A. Ayele).
}

oblique to its strike (Joffe and Garfunkel, 1978; Boccaletti et al., 1994, 1998; Dauteuil et al., 2001; Huchon and Khanbari, 2003). Several studies show that the Red Sea and the Gulf of Aden oceanic rifts are propagating on land in Afar (e.g. Courtillot, 1980, 1982; Acton and Stein, 1991; Manighetti et al., 1997, 1998, 2001; Fig. 1a) as a result of the separation of Arabia from Africa and the quiescence of the Bab El Mandeb in geologically recent times (Barberi et al., 1975; Figs. 1b and 4). The rheology of the lithosphere beneath the Afar Depression is weakened by one or more mantle plumes (Ebinger and Sleep, 1998; White and McKenzie, 1989) though the origin and present day location 
a
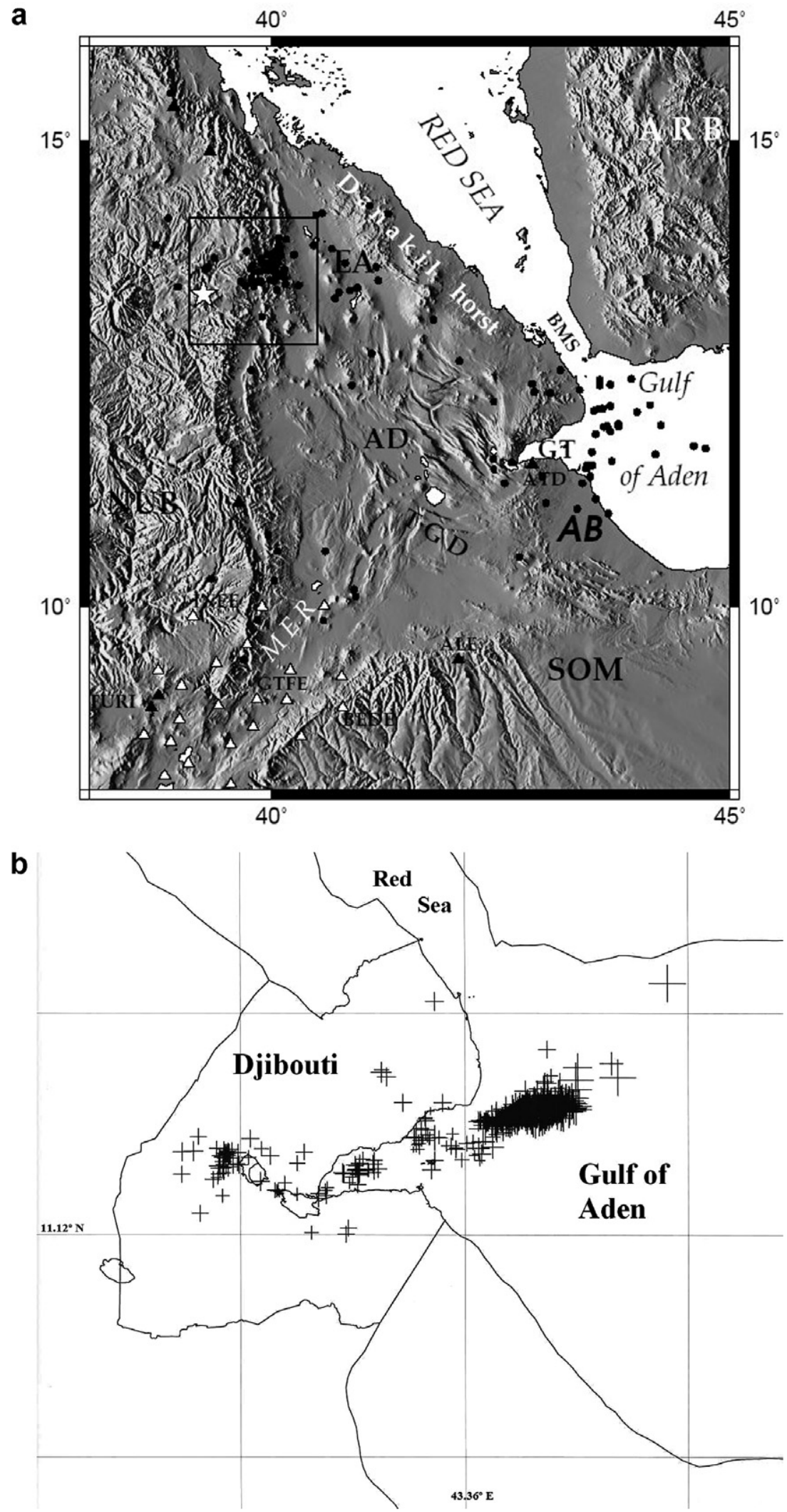

Fig. 1. (a) Gray color plot of the topography of the Afar triple junction. The white triangles represent the EAGLE temporary seismic broadband array and the black triangles show the permanent station locations in the region used in this study. The larger white star represents the location of Mekele town. AD, Afar Depression; GT, Gulf of Tadjoura; NUB, Nubia plate; SOM, Somalia plate; ARB, Arabia plate; MER, Main Ethiopian rift. The black circles show earthquakes distribution of the August 2002 activity located in this study. (b) Seismicity of the Djibouti and Gulf of Tadjoura area of August, 2002 as reported in the Arta seismic bulletin. 
of the plume remains controversial. This propagation of the Red Sea and Gulf of Aden rifts into Afar is in good agreement with the hypothesis that rifting occurring close to the boundary between continental and oceanic crust preferentially forms on continental crust because of its rheological weakness (Vink et al., 1984; Müller et al., 2001).

The interaction of three oblique rifts in a plume-affected lithosphere has resulted in complex tectonics in Afar, making deformation so distributed that rigid plate kinematics may not currently apply in the interior of Afar. The Red Sea and Gulf of Aden rifts have penetrated into Afar where they are now actively opening and propagating through the development of a series of disconnected rift segments (e.g. Barberi et al., 1972; Manighetti et al., 1998). At a smaller scale, deformation in Afar seems to have involved the rotation of at least two microplates (Danakil and Ali Sabieh blocks) sandwiched between the three major plates (Chu and Gordon, 1998; Eagles et al., 2002). From plate reconstructions, the Danakil microplate is inferred to have been part of Nubia at ca. $11 \mathrm{Ma}$, and since then to have rotated counter-clockwise about a pole at $19^{\circ} \mathrm{N}$ and $42^{\circ} \mathrm{E}$ (Chu and Gordon, 1998; Eagles et al., 2002). This model implies oblique-slip to strike-slip motion along the Danakil microplate's boundary with the Nubia plate and all along the Tendaho-Gobaad discontinuity in the Afar Depression.

From radar interferometeric measurement of ground surface displacement (Amelung et al., 2000), significant deformation of about $12 \mathrm{~cm}$ subsidence is observed in Erta Ale, one of the active volcanoes in Ethiopia. These processes are postulated to result from a combination of magma withdrawal from a large reservoir and normal faulting. This was the only identifiable deformation event during the period June, 1993 to October, 1997 in the $80 \mathrm{~km}$ long Erta Ale volcanic range, indicating considerable inactivity elsewhere in the range (Amelung et al., 2000). West of Erta Ale at the plateau margin, there were two periods of earthquake activity in August, 2002 and October, 2004.

Starting on August 7, 2002, the Mekele area was shaken by a series of earthquakes that occurred near the western margin of the Danakil microplate. The activity continued until the end of the month and the larger earthquakes were widely felt in several towns in northern Ethiopia (Beyeda, Jane-Amora, Adigrat, Woldia) and Asmara in Eritrea, causing panic in particular in Mekele town. The magnitude of the main shock is estimated to be $5.6 M_{\mathrm{w}}$ from our study. The objective of this paper is to study the August 2002 events, which formed the more significant of the two earthquake sequences mentioned above, and to interpret the results so as to shed light on the neotectonics of the Danakil microplate.

\section{Data and methods}

The earthquake sequence considered in this study was captured by the temporary Ethiopia Afar Geoscientific Lithospheric Experiment (EAGLE) phase I broadband network and other permanent seismic stations in Ethiopia, Djibouti and Eritrea (Fig. 1a). Most of the seismic stations used in the location lie to the south while the two Eritrean stations to the north are the nearest to the epicentral region (Fig. 1a). Earthquake locations and relocations are made using the Hypoinverse 2000 (Klein, 2002) and hypoDD (Waldhauser and Ellsworth, 2000) programs, respectively. A well-constrained 1-d velocity model (Daly et al., 2004) using the EAGLE controlled source experiment is used for locating earthquakes. To estimate the earthquake source parameters, we modeled the three component displacement waveforms from two or more stations, beginning with the first P-wave arrival and continuing through the surface wave train. Aligning at the first P-arrival and bandpass filtering in the range of $20-65 \mathrm{~s}$ both the observed and synthetic seismograms help to reduce our solution dependence on source location, origin time, and the assumed Earth model. In this bandwidth, almost all the data from the local stations have good signal-to-noise ratio both for the body and surface waves (Figs. 3a-c). Using complete waveforms from stations located at various azimuths and distances from the source (Fig. 1a) enables a robust estimate of source parameters. We made a time domain linear inversion with a least squares approach (Langston, 1981; Ammon et al., 1998). Green's functions used in the inversion were calculated using the reflectionmatrix method (Kennett, 1983) as implemented by Randall (1994). We used the same 1-d crustal structure model implemented for earthquake locations to generate the Green's functions.

The local magnitude, $\mathrm{M}_{\mathrm{L}}$, for each of the earthquakes in the sequence is estimated using the relation presented by Langston et al. (1998). The $b$-value is estimated for the earthquakes in the Mekele area, in the neighborhood of the black rectangle displayed in Fig. 1a using the maximum likelihood approach (Aki, 1965) and least squares to give an idea of the stress status of the seismogenic zone (Scholz, 1968). The $b$-value estimate by Hofstetter and Beyth (2003) for the area is 1.05 but calculated from only seven earthquakes with narrow spread in magnitude.

\section{Results and interpretation}

Earthquake locations, moment tensor inversions and $b$ value estimates are made for the August, 2002 earthquake sequence in north Afar.

\subsection{Earthquake locations}

From the August 2002 seismicity considered in this study, 75 earthquakes are associated with the plateau margin of the rift east of Mekele and the remaining 57 events are distributed in other active rift segments of the Afar region, mostly in the Gulf of Tadjoura (Fig. 1a). Because of the lack of data from Djibouti and Yemen, the Gulf of Tadjoura events are not well-constrained by our location but the Arta array bulletin for that month shows a clear 
pattern in the seismicity (Figs. 1a and b). The spatial and temporal distribution of this month-long period of major earthquake activity in the Afar region seem to indicate the northwestward propagation of the Gulf of Aden rift across the Afar Depression towards the western Ethiopian plateau. Only a few events in the Mekele area qualified to be relocated using the double-difference technique (Waldhauser and Ellsworth, 2000). Our relocated events are concentrated closer to the rift floor than the corresponding United States Geological Survey (USGS) locations, which are scattered toward the plateau (Figs. 2a and b).

\subsection{Moment tensor inversion}

Extensional fault plane solutions are obtained for the six larger earthquakes as estimated from moment tensor inversion of local broadband waveform data (Fig. 2a). A good waveform fit is obtained for the observed and synthetic seismograms (Figs. 3a-c). The seismic activity close to the rift margin east of Mekele town could be induced by either the NS trending border faults related to the Red Sea opening (Wolfenden et al., 2004) or by the NNWtrending faults related to the Gulf of Aden rift (e.g. Manighetti et al., 2001). We plotted the P-wave group of the broadband displacement seismograms (Fig. 2c) for five seismic stations at different azimuths from the main shock on August 10, 2002, expecting that the amplitude of the Pwave arrival will indicate if a station is nodal or not. Station GTFE would be expected to be nodal if the rupture were induced by a NS trending fault but doesn't appear to be. On the contrary it is clear to see that one nodal plane passes between stations ATD in Djibouti and ALE (ALME) on the eastern Ethiopian plateau (Figs. 1a and 2c), at azimuths of $125^{\circ}$ and $152^{\circ}$, respectively. This nodal plane, which seems to be the fault plane, passes close to station ATD. The distributions of the relocated events (Fig. 2b) show that the earthquakes ruptured on multiple faults trending NNW, consistent with tectonics of the area.

Of the six earthquakes studied with moment tensor inversion, the P-wave group of the broadband displace-
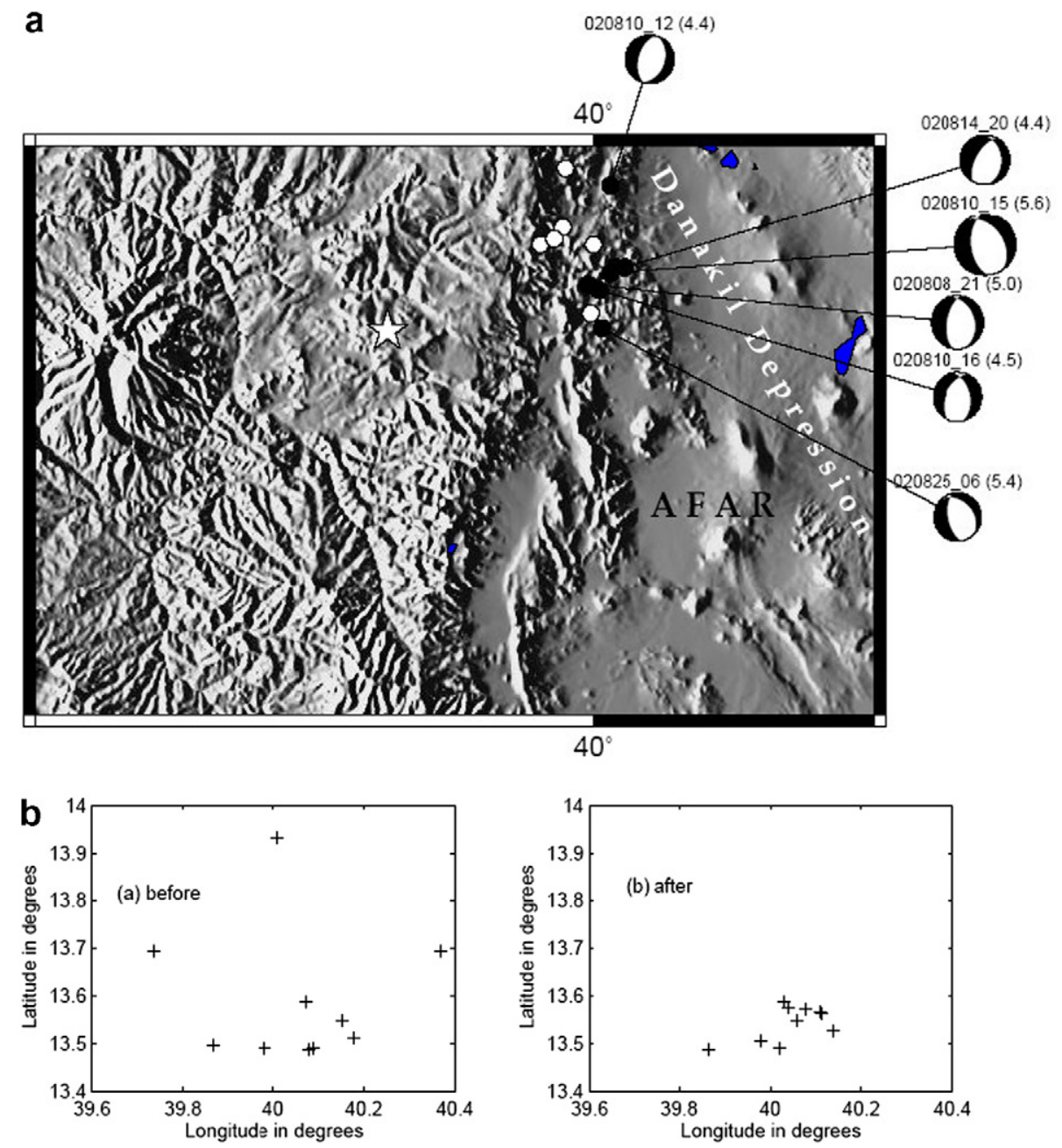

Fig. 2. (a) Plots of the six fault plane solutions determined in this study. White star: location of Mekele town, white circles: USGS locations for the six events, black circles: our locations. (b) Plots of earthquakes that qualified to be relocated using the double-difference technique before (left) and after (right) relocation. (c) Waveform plots of the P-wave group for the main shock as recorded at five stations and different azimuths. The origin time of the main shock is used as reference for the plots to all stations which are also at different distances. (d) The P-wave group plot of the six events as recorded at station INEE to waveform similarities of the different events. 

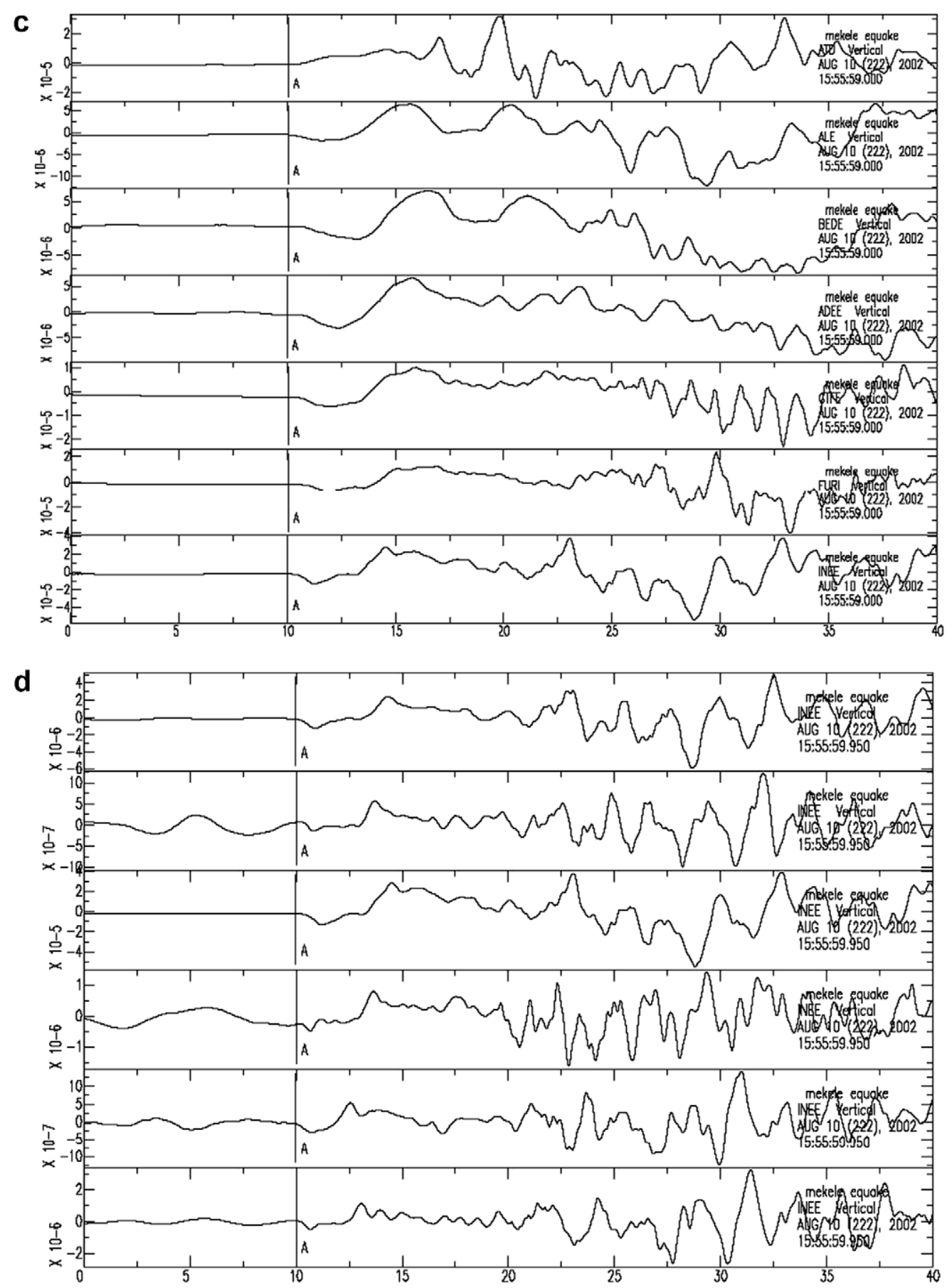

Fig 2. (continued)

ment seismograms for station INEE is plotted in Fig. 2d. The plots are arranged chronologically as listed in Table 1 but the start time of the main shock is assumed for all the traces so as to synchronize the waveforms in the figure. It is clear that all the waveforms are similar except for the August 10, 2002 aftershock indicating a similar rupture process. The August 10, 2002 aftershock has similar focal mechanisms to the others (Fig. 2a) but its waveform is slightly different. This event occurred an hour after and very close to, the main shock and the rupture process might be contaminated by transient seismic signals from the previous rock failure.

A summary of all our results (Figs. 2a-d) shows purely normal faulting on NNW trending and northeast dipping faults. Our results are consistent with previous work in the Bada area by Ghebreab and Solomon (1994) based on field observations of surface ruptures formed by the 1993 earthquake sequence and the corresponding Harvard CMT solution for the main shock. The October 22, 2004 earthquake occurred close to the 1993 event location and 


\section{a Vertical}
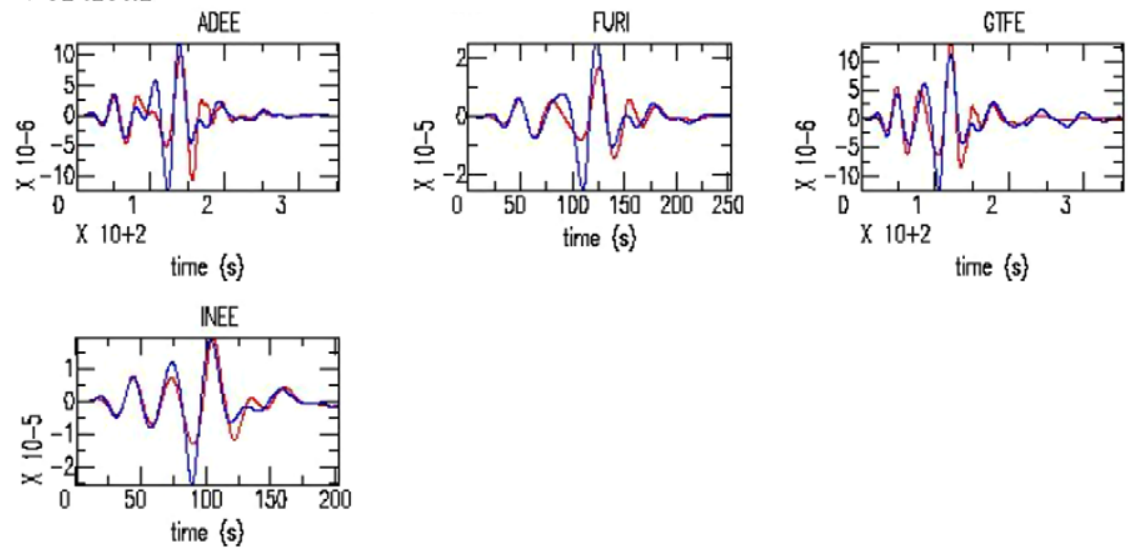

\section{b Radial}
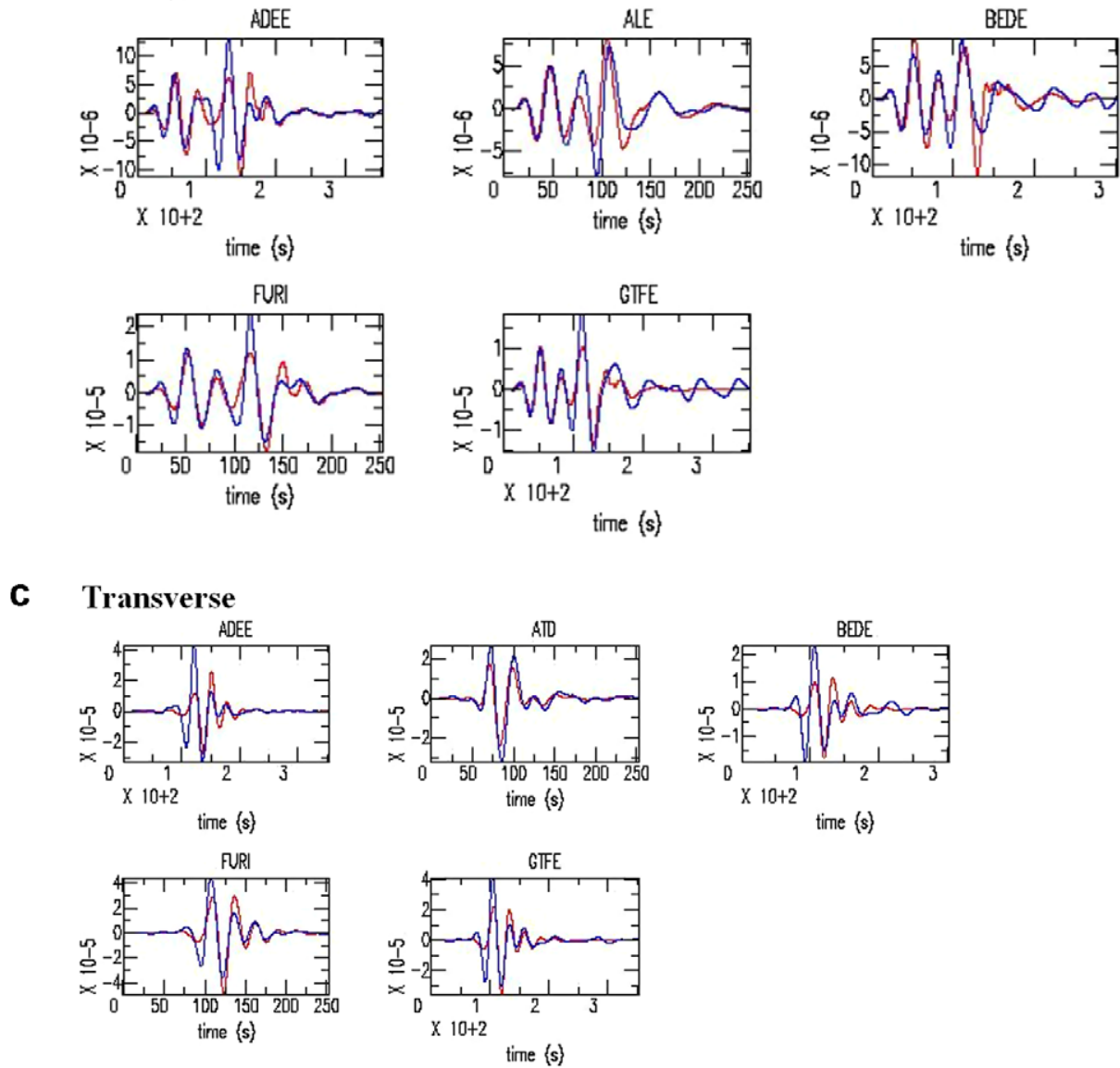

Fig. 3. Waveform fits of the observed and synthetic seismograms for the 2002/08/10_15 event: (a) vertical, (b) radial and (c) transverse components.

its CMT solution has a similar source mechanism to the others (Fig. 4, Table 1). No strike-slip component is observed in any of the fault plane solutions in our results to indicate oblique deformation between the Nubian plate and the Danakil microplate, as would have been expected if the microplate were rotating counter-clockwise with respect to the Nubian plate (Chu and Gordon, 1998; Eagles et al., 2002). This could be due to coupling of the Danakil horst with the Arabian plate at present and the major extensional deformation is taking place in Afar, which con- nects the Gulf of Aden and Red Sea oceanic rifts. There seems to be some seismic activity in the southern Red Sea (Fig. 4) but it attenuates southward and its regional significance may be minimal. This may mean that either Danakil-Arabia plate coupling is in the making or large strike-slip earthquakes are expected to happen in the future in Afar to justify the counter-clockwise rotation of the Danakil microplate and many have not yet been recorded except one in the 1969 Serdo sequence (Fig. 4). Hypocentral depths of the well-constrained events from the moment 
Table 1

Source parameters for the six large earthquakes of the August 2002 in north Afar

\begin{tabular}{|c|c|c|c|c|c|c|c|c|c|}
\hline No. & Date & Origin time & Latitude & Longitude & Depth $(\mathrm{km})$ & $M_{\mathrm{w}}$ & Strike & Dip & Rake \\
\hline 1 & $2002 / 08 / 08$ & $21: 17: 08.36$ & 13.5061 & 39.9798 & 5 & 5.0 & $312 / 146$ & $56 / 44$ & $260 /-79$ \\
\hline 2 & $2002 / 08 / 10$ & 12:01:18.68 & 13.8650 & 40.0653 & 6 & 4.4 & $361 / 196$ & $39 / 51$ & $258 /-80$ \\
\hline 3 & $2002 / 08 / 10$ & $15: 55: 58.41$ & 13.5475 & 40.0582 & 7 & 5.6 & $322 / 172$ & $41 / 53$ & $246 /-71$ \\
\hline 4 & $2002 / 08 / 10$ & $16: 45: 52.88$ & 13.4892 & 40.0193 & 6 & 4.6 & $296 / 145$ & $55 / 39$ & $249 /-63$ \\
\hline 5 & $2002 / 08 / 14$ & $20: 49: 22.56$ & 13.5665 & 40.1098 & 5 & 4.5 & $363 / 210$ & $35 / 58$ & $247 /-74$ \\
\hline 6 & $2002 / 08 / 25$ & $06: 02: 29.12$ & 13.4884 & 39.8645 & 6 & 4.4 & $317 / 143$ & $46 / 43$ & $265 /-85$ \\
\hline $7^{*}$ & $2004 / 10 / 22$ & $12: 00: 14.30$ & 14.4100 & 40.2500 & 12. & 5.4 & $326 / 170$ & $53 / 40$ & $255 /-71$ \\
\hline
\end{tabular}

The last list (*) indicates CMT solutions for the source parameters of the October 22, 2004 earthquake.

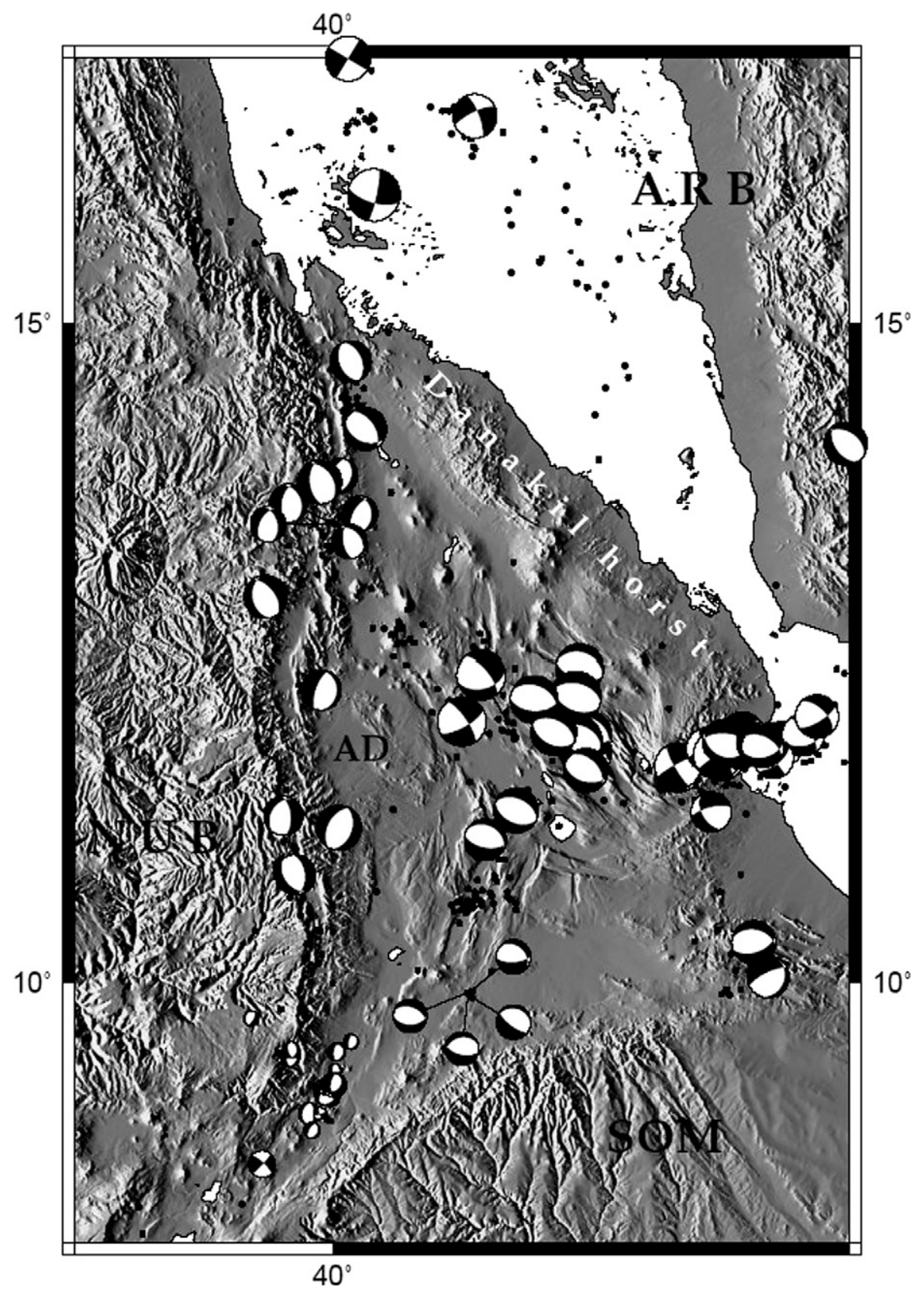

Fig. 4. Summary of all fault plane solutions in the specified spatial window from this study, Shudofsky (1985), Foster and Jackson (1998), Braunmiller and Nabelek (1990), Ayele et al. (2006), Keir et al. (2006) and Harvard CMT solutions. The beach-ball size is proportional to earthquake magnitude and other acronyms are as specified in Fig. 1a. 
tensor inversion are $5-7 \mathrm{~km}$, which is the approximate depth of the brittle-ductile transition zone in the Main Ethiopian rift (Ebinger and Hayward, 1996; Keranen et al., 2004; Ayele et al., 2006).

Fig. 4 summarizes all post-1960 seismicity in the region for magnitudes $m_{\mathrm{b}} \geqslant 4.5$, from this study, Ayele (1995), the USGS catalogue, Shudofsky (1985), Foster and Jackson (1998), Braunmiller and Nabelek (1990), Ayele et al. (2006), Keir et al. (2006) and Harvard CMT solutions. The $m_{\mathrm{b}} \geqslant 4.5$ seismicity is chosen to minimize location uncertainty in the region. The Red Sea and Gulf of Aden spreading centers have been propagating toward one another for some time but have not yet directly connected although extension patterns reminiscent of both have developed in Afar through the development of a series of disconnected, propagating rift segments (e.g. Manighetti et al., 1997). The Red Sea related rifts are Erta 'Ale, Tat'Ali, Alayta, Manda Hararo and Goba'ad while the Gulf of Aden related ones are the Tadjoura, Asal-Goubbet, Mak'arrasou and Manda Inakir rifts (Manighetti et al., 2001). If we compare these two groups, the Gulf of Aden group is more active than the Red Sea group (Fig. 4). As shown above in our data, the recent seismic activity near the western part of the Danakil microplate occurs on faults with an orientation similar to the NNW propagation of the Gulf of Aden rift.

We projected the summary of all fault plane solutions on Fig. 4 to see the dominant mode of deformation in the region and extract a simple working model. With the exception of sinistral strike-slip motion in southern Red Sea, dextral oblique-slip deformation in the Gulf of Tadjoura and one in the Serdo earthquake sequence of 1969, the boundaries of the Danakil microplate appear to be undergoing only extensional deformation, which demands differential motion along its boundary with the Nubian plate both at the plateau margin and in the Afar Depression. There is clear evidence for the counter-clockwise rotation of the Danakil microplate in its geologic past (Chu and Gordon, 1998; Eagles et al., 2002) which is not consistent with recorded seismicity in Afar (Fig. 4), and this invites more earthquake data analysis and GPS measurements in Nubia, Danakil and Arabia plates in coming years.

Most of the earthquakes in Afar occur at shallow depths of $<10 \mathrm{~km}$. At teleseismic distances, the $\boldsymbol{s} \boldsymbol{P}$ phase amplitude of those shallow earthquakes dominates the direct $\boldsymbol{P}$ and their arrival time difference is about 1-2 s. The sampling frequency of analog seismograms for long period signal analysis is $1 \mathrm{~Hz}$, which is almost the travel time difference of direct $\boldsymbol{P}$ and the surface reflected $\boldsymbol{s} \boldsymbol{P}$ phases. It is very likely that the $\boldsymbol{s} \boldsymbol{P}$ phase could be confused with the direct $\boldsymbol{P}$, especially for seismograms from WWSSN stations, which would result in faulty earthquake source mechanisms. The 1969 Serdo earthquakes are known to have strike-slip mechanisms (Mckenzie et al., 1970; Kebede et al., 1989) but, after thorough waveform analysis, some of them proved to be normal faults (Wagner and Langston, 1988; Foster and Jackson, 1998).

\section{3. $b$-Value}

A $b$-value is estimated for the August, 2002 earthquake sequence in north Afar using the maximum-likelihood approach (Aki, 1965) and least squares fitting (Fig. 5). The $b$-value is estimated to be 0.66 , as shown by the slope

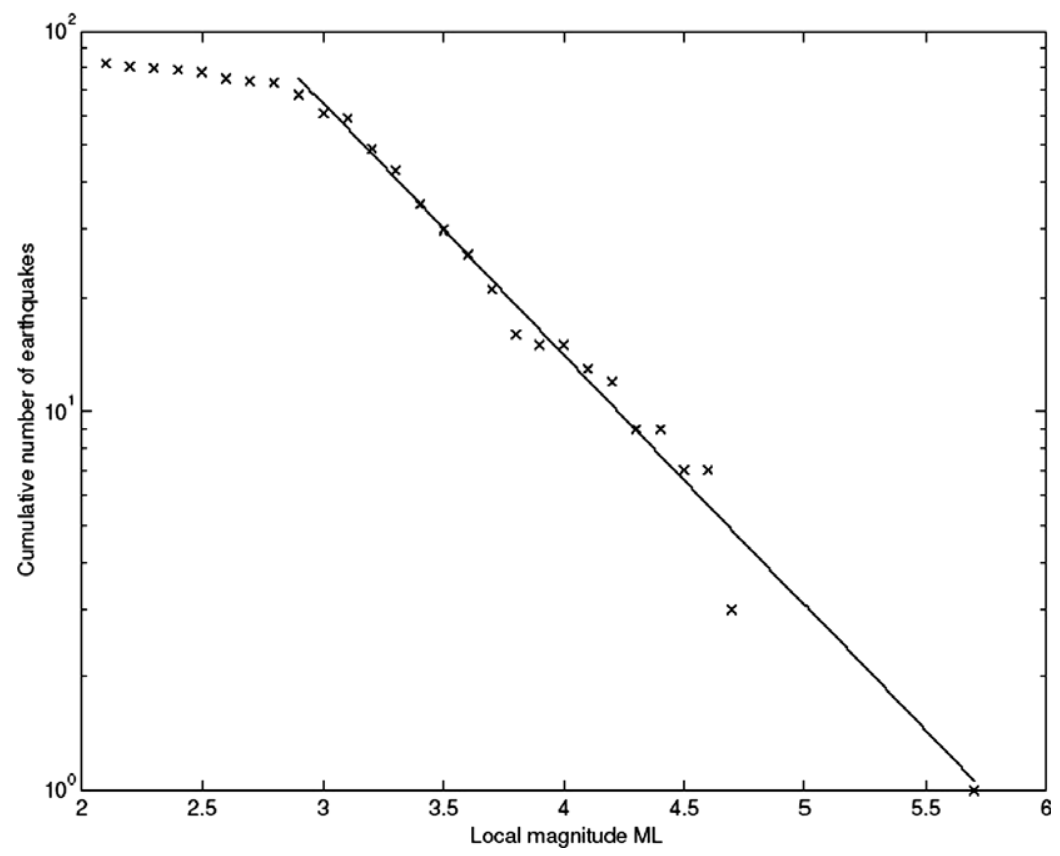

Fig. 5. Log normal plot of the cumulative number of earthquakes versus earthquake magnitudes. The curve is the least squares fit for the frequencymagnitude distribution curve. The threshold magnitude is $2.9 \mathrm{Ml}$. 
of the curve in Fig. 5, and this estimate is within the standard error of the maximum likelihood estimate of $0.67 \pm 0.16$. Our $b$-value estimate is lower than 1.05 obtained by Hofstetter and Beyth (2003) for the area from a less reliable data, indicating that the frequency of occurrence of relatively large magnitude earthquakes is higher than average, in turn implying that the Ethiopian plateau margin near the western part of the Danakil microplate is highly stressed.

\section{Summary}

Our fault plane solutions for six earthquakes studied from moment tensor inversion of local waveform data show normal faulting on NNW trending and ENE dipping normal faults. From the trend of our location for the August, 2002 earthquake activity in the Afar region, it seems that extension in this part of Afar is on faults related to the NNW propagation of the Gulf of Aden rift. From a summary of all fault plane solutions in the Afar region including our results, it is clear that there is no strike-slip motion at the boundary of the Danakil microplate except in the southern Red Sea and Gulf of Tadjoura, where the Red Sea and Gulf of Aden oceanic rifts enter into the Afar Depression, respectively. The extension in the Afar Depression is distributed and a rigid plate boundary is still in the making.

The shallowness of the earthquake depths agrees with reports of the widely felt seismicity in northern Ethiopia and the $b$-value estimate in this study shows that the plateau margin adjacent to the Danakil microplate is highly stressed. Potential future shallow crustal deformation and associated earthquakes could cause significant loss of human life and damage to property in the highly populated highland region of the Mekele area unless measures are taken to enforce the existing building code for earthquake resistant structures.

\section{Acknowledgements}

Ayele's visit to the Department of Earth Sciences, University of Leeds, is sponsored by the Royal Society of London. We would like to acknowledge Dr. C.A. Ammon for providing the moment tensor inversion code, mitinv. Thanks to George E. Randall for use of his reflectivity code for generating the green's functions; to Pål Wessel and Walter H.F. Smith for Generic Mapping Tools (GMT) and to Dr. Ghebrebrhan Ogubazghi for providing phase readings for two stations in Eritrea.

\section{References}

Acton, G.D., Stein, S., 1991. Block rotation and continental extension in Afar: a comparison to oceanic microplate systems. Tectonics 10 (3), 501-526.

Aki, K., 1965. Maximum Likelihood Estimate of $b$ in the Formula $\log N=a-b M$ and Its Confidence Limits. Bulletin Earthquake Research Institute, Tokyo University, pp. 237-239.
Amelung, F., Oppenheimer, C., Segall, P., Zebker, H., 2000. Ground deformation near Gada 'Ale Volcano, Afar, observed by radar interferometry. Geophysical Research Letters 27 (19), 3093-3096.

Ammon, C.J., Herrmann, R.B., Langston, C.A., Benz, H., 1998. Faulting parameters of the January 16, 1994 Wyomissing Hills, Pennsylvania earthquakes. Seismological Research Letters 69 (3), 261-269.

Ayele, A., 1995. Earthquake catalogue of the horn of Africa for the period 1960-1993. Seismological Department, Uppsala University, Report 395, pp. 1-9.

Ayele, A., Nyblade, A.A., Langston, C.A., Cara, M., Leveque, J.-J., 2006. New evidence for Afro-Arabian plate separation in south Afar. In: Yirgu, G., Ebinger, C.J., Maguire, P.K.H. (Eds.), The Afar Volcanic Province in the East African Rift System, vol. 256. Geological Society, London, pp. 133-141 (Special Publications).

Barberi, F., Borsi, S., Ferarra, G., Marinelli, G., Santacroce, R., Tazieff, H., Varet, J., 1972. Evolution of the Danakil Depression (Afar, Ethiopia) in light of radiometric age determinations. Journal of Geology 80, 720-729.

Barberi, F., Ferrara, G., Santacroce, R., Varet J., 1975. Structural evolution of the Afar triple junction. In: Pilger, A., Rosler, A. (Eds.), Afar Depression of Ethiopia. Schweitzerbart, Stuttgart, pp. 38-54.

Bilham, R., Bendick, R., Larson, K., Mohr, P., Braun, J., Tesfaye, S., Asfaw, L., 1999. Secular and tidal strain across the main Ethiopian rift. Geophysical Research Letters 26 (18), 2789-2792.

Boccaletti, M., Mammo, T., Bonini, M., Abebe, B., 1994. Seismotectonics of the East African rift system: evidence of active oblique rifting. Annales Tectonicae 8, 87-99.

Boccaletti, M., Bonini, M., Mazzuoli, R., Abebe, B., Piccardi, L., Tortorici, L., 1998. Quaternary oblique extensional tectonics in the Ethiopian rift (Horn of Africa). Tectonophysics 287, 97-116.

Braunmiller, J., Nabelek, J., 1990. The 1989 Ethiopia earthquake sequence. EOS, Transactions of the American Geophysical Union $71,1480$.

Chu, D., Gordon, R.G., 1998. Current plate motions across the Red Sea. Geophysical Journal International 135, 313-328.

Cochran, J.R., 1981. The Gulf of Aden: structure and evolution of a young ocean basin and continental margin. Journal of Geophysical Research 86 (b1), 263-287.

Courtillot, V., 1980. Opening of the Gulf of Aden and Afar by progressive tearing. Physics of the Earth and Planetary Interiors 21, 343-350.

Courtillot, V., 1982. Propagating rifts and continental breakup. Tectonics $1,239-256$.

Daly, E., Keir, D., Ebinger, C.J., Stuart, G., Ayele, A., Waltham, D., 2004. Crustal structure of the northern Main Ethiopian rift from a tomographic inversion of local earthquakes. In: Yirgu, G. et al. (Eds.), Proceedings of the International Conference on the East African Rift System, June 20-24 2004, Addis Ababa. Ethiopian Geoscience and Mineral Engineering Association, Ethiopia, pp. 51-52.

Dauteuil, O., Huchon, P., Quemeneur, F., Souriot, T., 2001. Propagation of an oblique rift: the western Gulf of Aden. Tectonophysics 332, 423 442.

Eagles, G., Gloaguen, R., Ebinger, C., 2002. Kinematics of the Danakil microplate. Earth and Planetary Science Letters 203, 607-620.

Ebinger, C.J., Hayward, N.J., 1996. Soft plates and hot spots: views from Afar. Journal of Geophysical Research 101 (B10), 21859-21876.

Ebinger, C., Sleep, N.H., 1998. Cenozoic magmatism in central and east Africa resulting from impact of one large plume. Nature 395, 788-791.

Foster, A.N., Jackson, J.A., 1998. Source parameters of large African earthquakes: implications for crustal rheology and regional kinematics. Geophysical Journal International 134, 422-448.

Ghebreab, W., Solomon, S., 1994. Recent formation of graben-in-graben structure at Bada of northern Dankalia, Eritrea. Geocience and Development 1, 16-18.

Hofstetter, R., Beyth, M., 2003. The Afar Depression: interpretation of the 1960-2000 earthquakes. Geophysical Journal International 155, $715-732$.

Huchon, P., Khanbari, K., 2003. Rotation of the syn-rift stress field of the northern Gulf of Aden margin, Yemen. Tectonophysics 364, 147-166. 
Joffe, S., Garfunkel, Z., 1978. Plate kinematics of the circum Red Sea-a re-evaluation. Tectonophysics 141, 5-22.

Kebede, F., Kim, W.-Y., Kulhanek, O., 1989. Dynamic source parameters of the March-May 1969 Serdo earthquake sequence in central Afar, Ethiopia, deduced from teleseismic body waves. Journal of Geophysical Research 94, 5603-5614.

Keir, D., Ebinger, C., Stuart, G., Daly, E., Ayele, A., 2006. Strain accommodation by magmatism and faulting as rifting proceeds to breakup: Seismicity of the northern Ethiopian rift. Journal of Geophysical Research 111, B05314. doi:10.1029/2005JB003748.

Kennett, B.L.N., 1983. Seismic wave propagation in stratified media. Cambridge University Press, Cambridge, England, 342 pp.

Keranen, K., Klemperer, S.L., Gloaguen, R.EAGLE working group, 2004. Three-dimensional seismic imaging of a protoridge axis in the Main Ethiopian rift. Bulletin of the Geological Society of America 32 (11), 949-952.

Klein, F.W., 2002. User's Guide to Hypoinverse-2000, a Fortran program to solve for earthquake locations and magnitudes. USGS Open File Report, 02-171, pp. 1-171.

Langston, C.A., 1981. Source inversion of seismic waveforms: the Koyna, India, earthquakes of 13 September, 1967. Bulletin of the Seismological Society of America 71, 1-24.

Langston, C.A., Brazier, R., Nyblade, A.A., Owens, T.J., 1998. Local magnitude scale and seismicity rate for Tanzania, East Africa. Bulletin of the Seismological Society America 88 (3), 712-721.

Manighetti, I., Tapponnier, P., Courtillot, V., Gruszow, S., Gillot, P.-G., 1997. Propagation of rifting along the Arabia-Somalia plate boundary: the Gulfs of Aden and Tadjoura. Journal of Geophysical Research 102, 2681-2710.

Manighetti, I., Tapponnier, P., Gillot, P.-G., Courtillot, V., Jacques, E., Ruegg, J.C., King, G., 1998. Propagation of rifting along the ArabiaSomalia plate boundary: into Afar. Journal of Geophysical Research 103, 4947-4974.
Manighetti, I., Tapponnier, P., Gillot, P.-G., Courtillot, V., Gallet, Y., 2001. Strain transfer between disconnected, propagating rifts in Afar. Journal of Geophysical Research 106 (B7), 13613-13665.

Mckenzie, D.P., Davies, D., Molnar, P., 1970. Plate tectonics of the Red Sea and East Africa. Nature 226, 243-248.

Müller, R.D., Gaina, C., Roest, W., Hansen, D.L., 2001. A recipe for microcontinent formation. Geology 29, 203-206.

Randall, G.E., 1994. Efficient calculation of complete differential seismograms for laterally homogeneous earth models. Geophysical Journal International 118, 245-254.

Scholz, C., 1968. The frequency-magnitude relation of microfracturing in rocks and its relation to earthquakes. Bulletin of the Seismological Society of America 58 (1), 399-415.

Shudofsky, G.N., 1985. Source mechanisms and focal depths of East African earthquakes using Rayleigh-wave inversion and body-wave modeling. Geophysical Journal of the Royal Astronomical Society 83, 563-614.

Vink, G.E., Morgan, W.J., Zhao, W.L., 1984. Preferential rifting of continents: a source of displaced terranes. Journal of Geophysical Research 89, 10072-10076.

Wagner, G.S., Langston, C.A., 1988. East African earthquake body wave inversion with implications for continental structure and deformation. Geophysical Journal 94, 503-518.

Waldhauser, F., Ellsworth, W.L., 2000. A double-difference earthquake locationalgorithm: method and application to the northern Hayward fault, California. Bulletin of the Seismological Society of America 80, $1368-1548$.

White, R., McKenzie, D., 1989. Magmatism at rift zones: the generation of volcanic continental margins and flood basalts. Journal of Geophysical Research 94 (B6), 7685-7729.

Wolfenden, E., Ebinger, C.J., Yirgu, G., Deino, A., Ayalew, D., 2004. Evolution of the northern Main Ethiopian rift: birth of a triple junction. Earth and Planetary Science Letters 224, 213-228. 